\title{
Aplikasi Sampling (Sampah Lingkungan) Pengrajin Sampah Berbasis Web Menggunakan Metode RAD (Rapid Application Development)
}

\author{
Nani Purwati, Fitra Nois Dwitama, Sri Kiswati \\ ${ }^{1}$ Sistem Informas Akuntansi, Universitas Bina Sarana Informatika \\ Indonesia \\ ${ }^{2}$ Sistem Informasi, Universitas Bina Sarana Informatika \\ Indonesia \\ ${ }^{3}$ Sistem Informasi, Universitas Bina Sarana Informatika \\ Indonesia \\ *Corresponding Author.E-mail:nani.npi@bsi.ac.id,sri.srk@bsi.ac.id
}

\begin{abstract}
Garbage is a waste material from human activities that has no use, with a population that continues to increase and exceeds the limit so that the amount of waste which also continues to increase will result in the accumulation of garbage. Based on observational data, entrepreneurs who care about the environment or waste recycling have problems in marketing products because they still use an offline system and the difficulty of reaching the sale of recycled products to the community besides that it can also serve as education on how to use waste. Therefore, website information media is a promotional media that is practical, effective, and efficient in promotion. Through the web, consumers are able to access information quickly according to their respective needs. The software design method used is RAD (Rapid Application Development) with the final result in the form of a web-based sampling application. The results of testing the functionality of the Sampling (Environmental Waste) website using the Black Box Testing method show the expected results. This application makes it easier for sales transactions and services for the manufacture of environmental waste products.
\end{abstract}

\section{Keywords: application, sampling, RAD, Rapid Application Development}

\section{Abstrak}

Sampah adalah material sisa dari aktivitas manusia yang tidak memiliki keterpakaian, dengan jumlah penduduk yang terus meningkat dan melebihi batas sehingga jumlah sampah yang juga terus bertambah akan mengakibatkan penumpukan sampah. Berdasarkan data observasi, pengusaha peduli lingkungan atau daur ulang sampah memiliki kendala dalam pemasaran produk karena masih menggunakan sistem offline dan sulitnya menjangkau penjualan produk daur ulang ke masyarakat selain itu juga dapat sebagai edukasi bagaimana cara pemanfaatan limbah sampah. Oleh karena itu, media informasi website merupakan media promosi yang praktis, efektif, dan efisien dalam promosi. Melalui web konsumen mampu mengakses informasi secara cepat sesuai kebutuhannya masing-masing. Metode perancangan perangkat lunak yang 
dipakai adalah RAD (Rapid Application Development) dengan hasil akhir berupa aplikasi Sampling berbasis web.Hasil pengujian fungsionalitas dari website Sampling (Sampah Lingkungan) dengan menggunakan metode Black Box Testingmenunjukkan hasil sesuai yang diharapkan. Aplikasi ini, memudahkan dalam transaksi penjualan dan pelayanan jasa pembuatan produk hasil sampah lingkungan.

\section{Kata kunci: aplikasi; sampling; RAD;Rapid Application Development}

\section{Introduction}

Kehadiran sampah merupakan salah satu persoalan yang dihadapi oleh masyarakat. Sampah adalah material sisa dari aktivitas manusia yang tidak memiliki keterpakaian, akibatnya sampah dapat menimbulkan kerugian karena akan menyebabkan banjir, meningkatnya pemanasan iklim, menimbulkan bau busuk, mengganggu keindahan, memperburuk sanitasi lingkungan(Yudhistirani et al., 2016). Data sampah tahun 2017 menurut data BLH di Kabupaten Bantul, Daerah Istimewa Yogyakarta, volume sampah anorganik yang dihasilkan oleh 215.678 keluarga mencapai $2.190,43 \mathrm{~m}^{3}$ per-hari, sedangkan volume sampah yang terangkut $131,37 \mathrm{~m}^{3}$ atau $6,00 \%$ (Setiadi, 2015). Berdasarkan data tersebut, sampah menjadi masalah serius yang dihadapi oleh masyarakat dan pemerintah terutama di kota-kota besar seperti Yogyakarta. Dengan jumlah penduduk yang terus meningkat dan melebihi batas sehingga jumlah sampah yang juga terus bertambah akan mengakibatkan penumpukan sampah. Sumber sampah bisa darimana saja diantaranya berasal dari rumah tangga, pasar, restoran, hotel, industri dan jalan.

Semakin banyak limbah sampah di lingkungan masyarakat sehingga sebagian masyarakat menjadikan aktivitas kebiasaan membuang sampah dengan sembarangan, karena kurangnya kesadaran dan pengetahuan masyarakat dalam memanfaatkan limbah sampah. Kesempatan ini menjadi peluang bagi pengusaha peduli lingkungan untuk memanfaatkan limbah sampah khususnya limbah sampah anorganik, dengan cara mendaur ulang sampah yang di kumpulkan dari masyarakat kemudian diolah menjadi suatu barang yang memiliki nilai jual.

Sebagian pengusaha peduli lingkungan memiliki beberapa kendala diantaranya sulit dalam mengumpulkan limbah sampah anorganik sebagai bahan dasar daur ulang. Oleh karena itu, dibutuhkan kerjasama dengan masyarakat dalam pengumpulan limbah sampah. Selain itu, masyarakat akan diberi pengetahuan dalam pemanfaatan pengelolaan sampah. Dari hasil pengumpulan sampah dibuat suatu produk jadi yang memiliki nilai jual, kemudian produk hasil daur ulang tersebut dijual kembali di masyarakat. Berdasarkan data observasi, pengusaha pengelola daur ulang sampah memiliki kendala dalam pemasaran produk karena masih menggunakan sistem offline. Dampak pemasaran dan promosi dengan sistem offline yaitu jangkauan terbatas, sehingga belum diketahui oleh masyarakat luas.

Penelitian sebelumnya oleh (Buani \& Suryani, 2020) berhasil membangun aplikasi jasa travel menggunakan metode waterfall, dan terbukti efektif meningkatkan pelayanan terhadap pelanggan. Selain itu, penelitian yang dilakukan oleh (Purwat 
\&Anggreani, 2020), berhasil membangun sistem informasi berbasis web menggunakan metode Rapid Application Development (RAD) dan efektif memberikan solusi atas permasalahan yang ada. Metode RAD dapat digunakan dalam pembangunan sistem informasi (Andriani \& Qurniati, 2018) serta pengujian blackbox testing dapat digunakan untuk pengujian aplikasi yang telah dibangun.Black Box Testing, pengujian dilakukan dengan cara mengeksekusi unit atau modul, kemudian dievaluasi apakah hasil sesuai atau tidak dengan proses bisnis yang diinginkan(Kusniawan, 2016).Hasil penelitian (Fauzi \& Harli, 2017) menunjukkan bahwa metode RAD mampu mempercepat proses pembangunan sistem CRM serta dapat sesuai dengan kebutuhan pelaku usaha.

Penelitian ini bertujuan membangun aplikasi sampah lingkungan (sampling), menggunakan metode pengembangan perangkat lunakRapid Application Development (RAD). Tujuan akhir penelitian ini adalah sebuah aplikasi berbasis web yang dapat memberikan solusi atas permasalahan yang sudah diuraikan diatas. Beberapa penelitian sebelumnya berfokus pada pengelolaan sampah lingkuan dilakukan oleh (Wardhana et al., 2019), pada penelitian trsebut hanya membahasa bagimana mengelolah data nasabah yang ada pada Bank Sampah Malang dengan mengembangkan aplikasi sampah berbasis android. Dengn studi kasus yang sama, penelitian mengenai Aplikasi sampah juga dilakukan oleh (Marali et al., 2018) dengan membangun aplikasi sampah berbasis web. Penelitian yang serupa juga dilakukan oleh (Rokhim \& Romadhoni, 2020), penulis membangun aplikasi untuk memudahkan bank sampah dalam proses administrasinya menggunakan metode extreme progrmamming (XP). Sedangkan penelitian lain juga dilakukan oleh (Kai et al., 2018)pembangunan Aplikasi Layanan Pengangkutan Sampah Berbasis Android metode RAD serta IDE Android Studio pembuatan sistem berbasis pemrograman berorientasi objek menggunakan Java. Selain itu, (Huda, 2019) juga membangun aplikasi sistem pelaporan sampah berbasis menggunakan metode waterfall, hasil dari aplikasi yang dibangun mampu mempermudah pengola sampah dalam monitoring sistem pelaporan serta rekap data.

Dari beberapa penelitan tersebut hanya mencakup ruang lingkup berupa pencatatan data nasabah, sistem informasi pelaporan bank sampah yang bertujuan memudahkan pengelola sampah dan nasabah dalam hal administrasinya. Oleh karena itu, dalam penelitian ini berfokus pada pembangunan aplikasi sampah lingkungan tentang media promosi produk hasil limbah lingkungan meliputi informasi layanan harga produk, daftar detail atau spesifikasi produk, dan jasa pemesanan produk hasil daur ulang sampah lingkungan.

\section{Materials and Methods}

Data penelitian diperoleh dari para pengrajin limbah di wilayah yogyakarta. Adapun metode pengembangan perangkat lunak dan metode pengumpulan data, penulis uraikan sebagai berikut:

\subsection{Metode Pengembangan Sistem}

Rapid Application Development (RAD) adalah metode pengembangan sistem informasi dengan waktu singkat, sehingga dinilai tepat digunakan dalam pembangunan 
suatu sistem informasi(Wahyuningrum \& Januarita, 2014). Tahapan yang digunakan dalam metode RAD adalah:

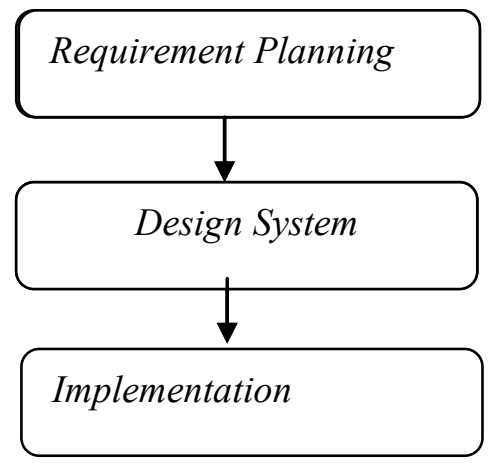

Sumber: (Wahyuningrum \& Januarita, 2014)

Gambar 2.1 Tahapan RAD

Pada tahap requirement planning penulis melakukan identifikasi kebutuhan serta melibatkan para pengrajin limbah dari wilayah Yogyakarta. Kemudian, pada tahap design system penulis mulai merancang desain sistem seperti erd, lrs, maupun database untuk kebutuhan dalam membangun aplikasi. Tahap yang ketiga adalah implementasi. Pada tahap ini penulis mengembangkan desain untuk kemudian hasil aplikasi yang sudah dibangun, diuji menggunakan metode blackbox testing.

\subsection{Metode Pengumpulan Data}

\section{1) Observasi}

Menurut Mania dalam(Andriani \& Qurniati, 2018)bahwa "Pengamatan atau observasi merupakan sebuah metode yang digunakan untuk mengumpulkan keterangan atau data dengan cara mengamati dan mencatat fenomena-fenomena yang terjadi pada sasaran pengamatan". Penulis melakukan observasi secara offline maupun online, yaituenulis mengamati 2 pengrajin limbah lingkungan yaitu Threadauptic, Dluwang, dan Kres Kros. Hasil dari observasi antara lain mengetahui proses menerima orderan dan lama pengerjaan, contoh produk yang sudah dijahit, promosi yang ada, fasilitas yang disediakan. Kemudian observasi online, penulis menggunakan website ecommerce untuk melihat aktivitas didalam website tersebut dan sebagai acuan untuk melengkapi data. Website yang diamati antara lain Dluwang, Kres Kros , Threadauptic hasil dari observasi antara lain mengamati jenis jasa yang tersedia, menumenu yang tersedia pada website tersebut, cara order, fasilitas yang ada.

2) Studi Pustaka

Metode pengumpulan data melalui studi artikel, media internet, dan sumber dari buku yang dapat dijadikan panduan dalam penyusunan laporan ini. Penulis mengumpulkan dan mempelajari buku-buku yang berkaitan dengan program aplikasi yang dibuat, laporan cetak, maupun laporan elektronik agar menghasilkan aplikasi yang efisien dan efektif.

\section{Results and Discussion}

Hasil dari penelitian ini berupa aplikasi sampah lingkungan (sampling) yang mampu membantu para pengusaha produk daur ulang sampah lingkungan memasarkan produknya dengan jangkauan yang lebih luas melalui website. Metode metode pengembangan perangkat lunakRapid Application Development (RAD) yang digunakan dalam penelitian ini mampu mempercepat proses pembangunan aplikasi dan berkesesuaian dengan penelitian yang dilakukan oleh (Fauzi \& Harli, 2017). Berbeda dari beberapa penelitian sebelumnya yang dilakukan oleh (Kai et al., 2018) yang hanya berfokus pada aplikasi layanan pengangkutan sampah. Begitu juga penelitian yang dilakukan oleh (Rokhim \& 
Romadhoni, 2020) dan (Nurhadi, 2018) yang juga berfokus pada bank sampah. Hasil penelitian yang penulis lakukan berupa aplikasi yang tidak hanya berfokus dalam pemungutan sampah atau penyetoran sampah yang dilakukan oleh masyarakat akan tetapi juga berupa pemasaran produk daur ulang sampah.

\subsection{Rancangan ERD}

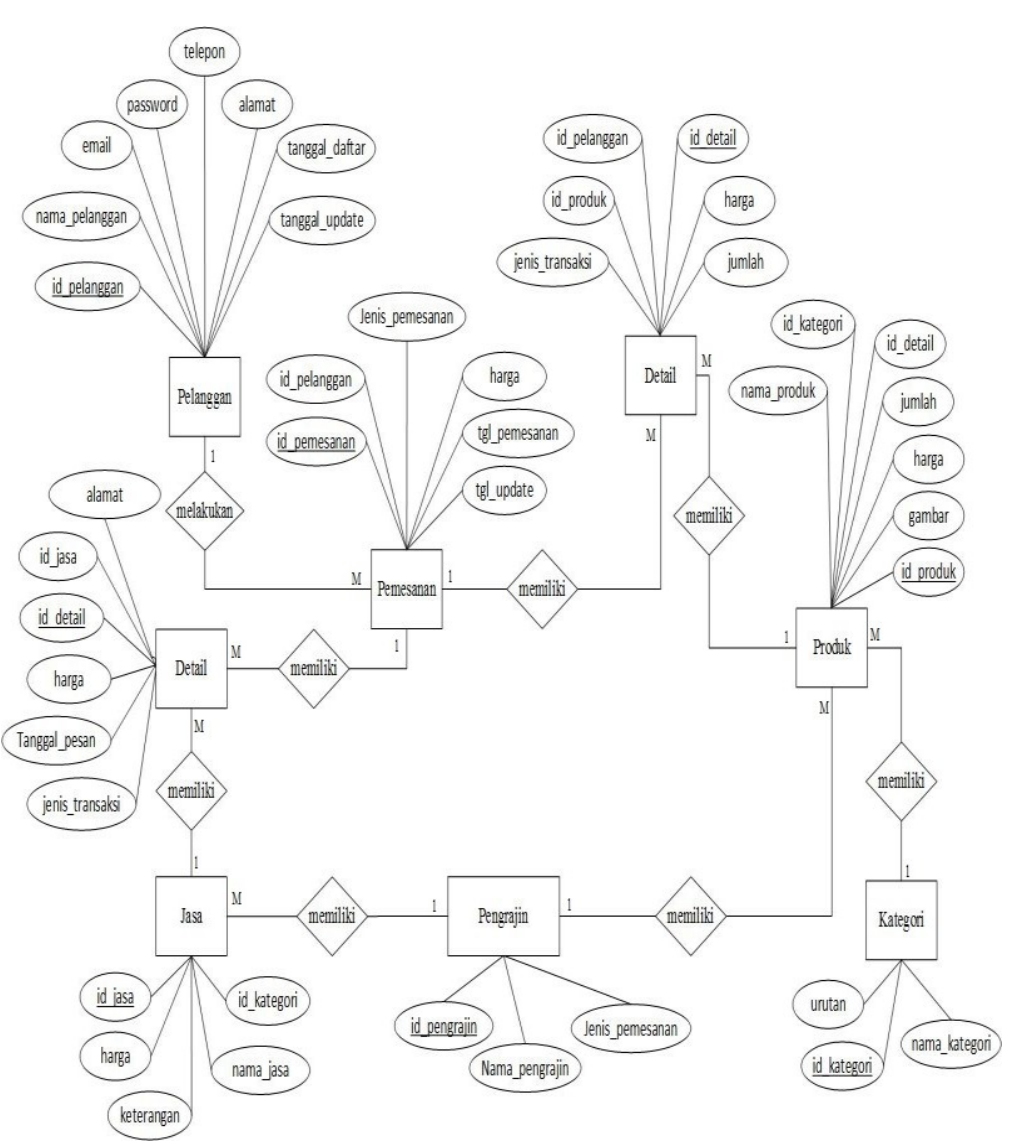

Gambar 3.1 Entity Relationship Diagram

Website SampLing

\subsection{Implementasi}

Implementasi rancangan antar muka pada website layanan SampLing berdasarkan hasil rancangan antar muka.

1) Halaman Login Admin
Admin harus melakukan login terlebih dahulu untuk dapat menggunakan modulmodul yang tersedia. Jika login berhasil, maka menu-menu yang sesuai dengan kategori akun dan katasandi tersebut akan

\section{SampLing (Admin)}

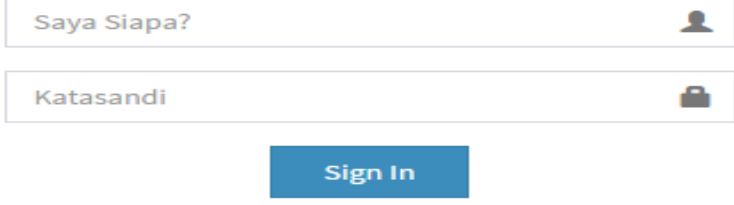

ditampilkan.

2) Menu dasbor Admin

Halaman menu Admin setelah login.

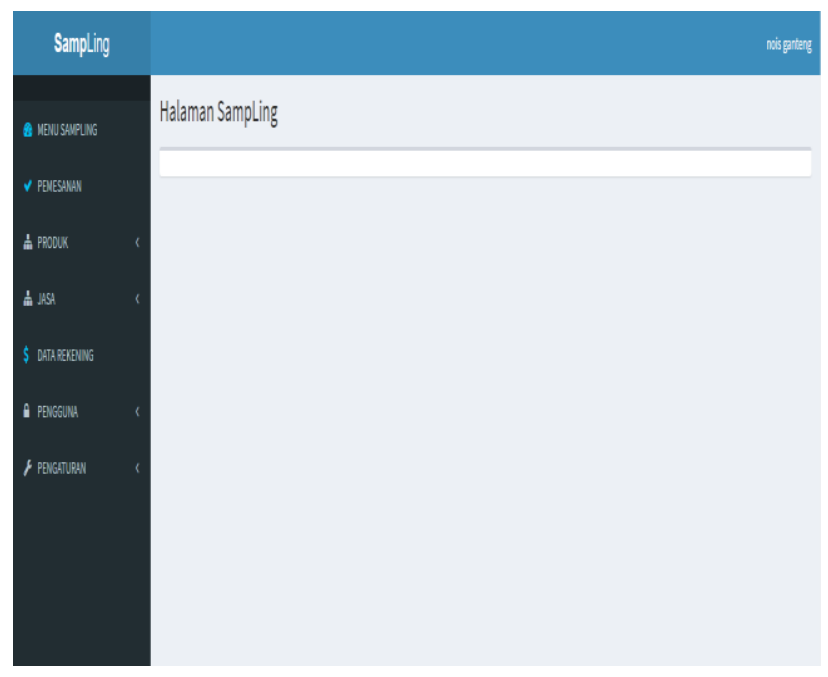

Gambar 3.3.2 Menu Dasbor Admin

3) Halaman utama Pelanggan

Halaman utama yang dapat diakses oleh pelanggan dan pengunjung. 


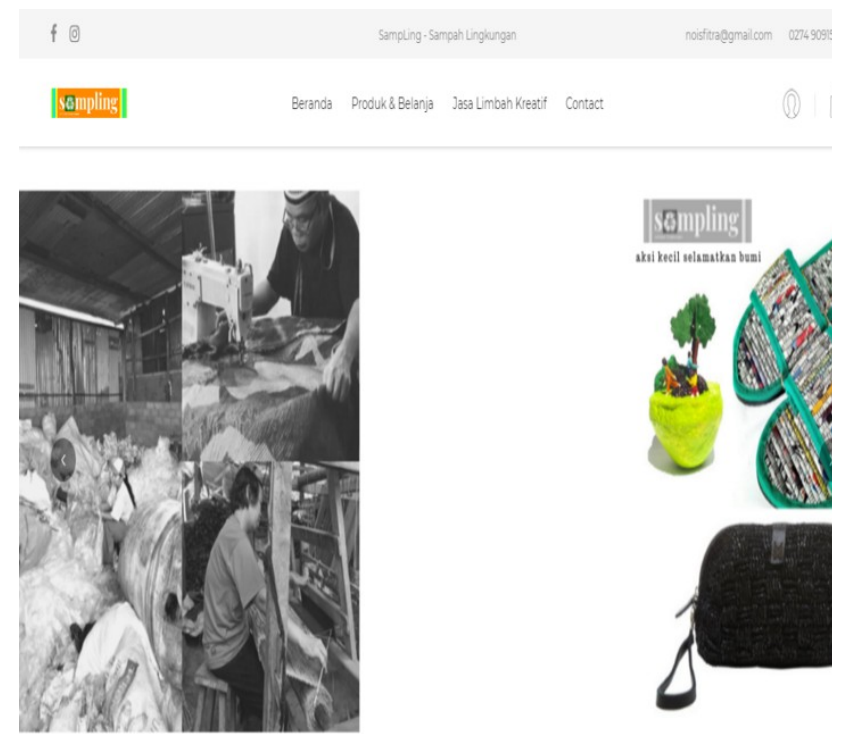

PILIH PRODUK TERBARU

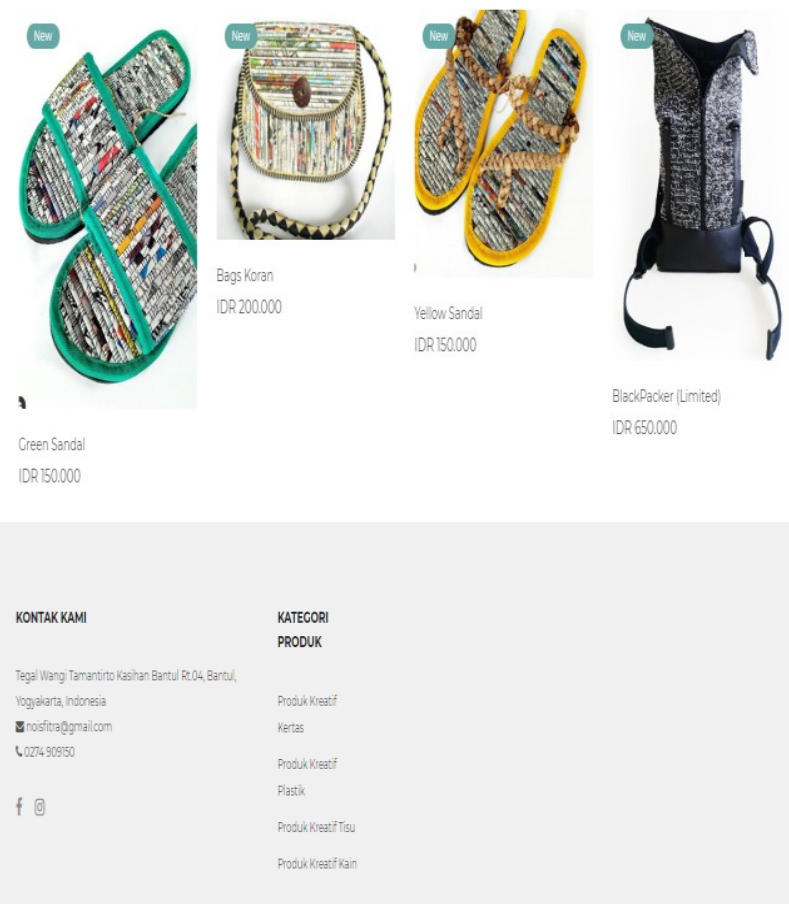

Gambar 3.3.3 Menu Utama Pelanggan

4) Halaman Registrasi Pelanggan

Halaman untuk registrasi pengunjung, sebelum melakukan pembayaran atau transaksi

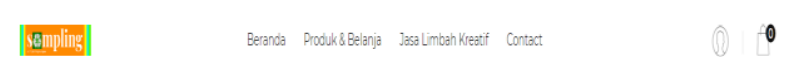

Registrasi Pelanggan

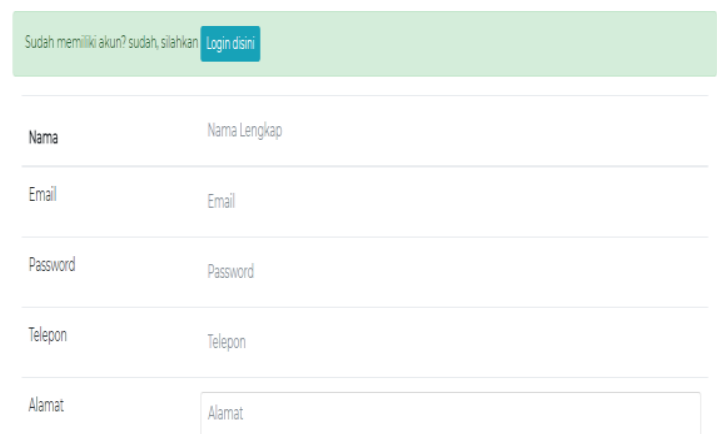

MSuomit X Reset

Gambar 3.3.4 Menu Registrasi Pelanggan

5) Halaman produk

Halaman produk, untuk pengunjung dan pelanggan
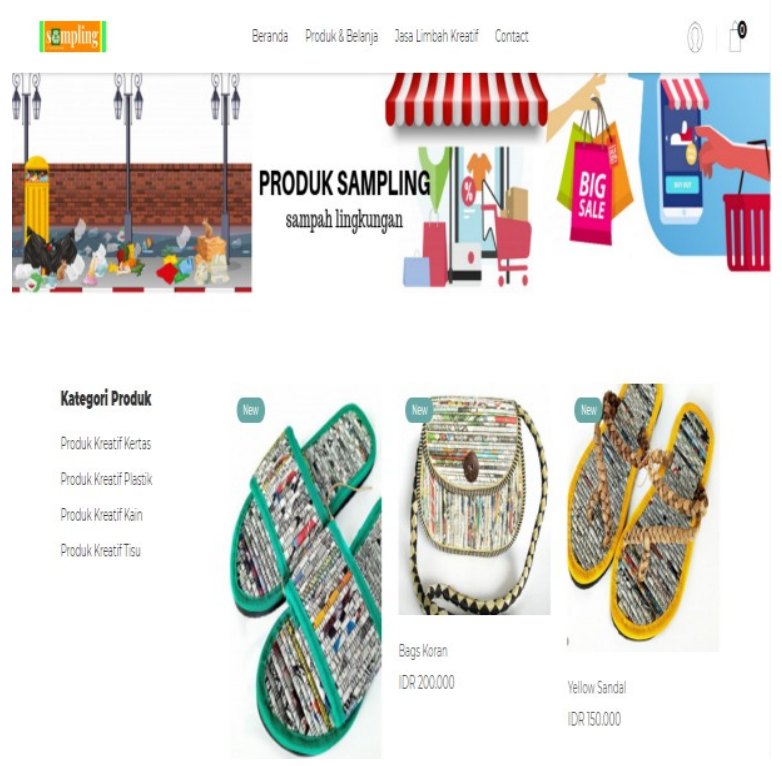

Gambar 3.3.5 Halaman Produk 
6) Halaman Keranjang Belanja

Halaman keranjang belanja, untuk memproses pembelanjaan.
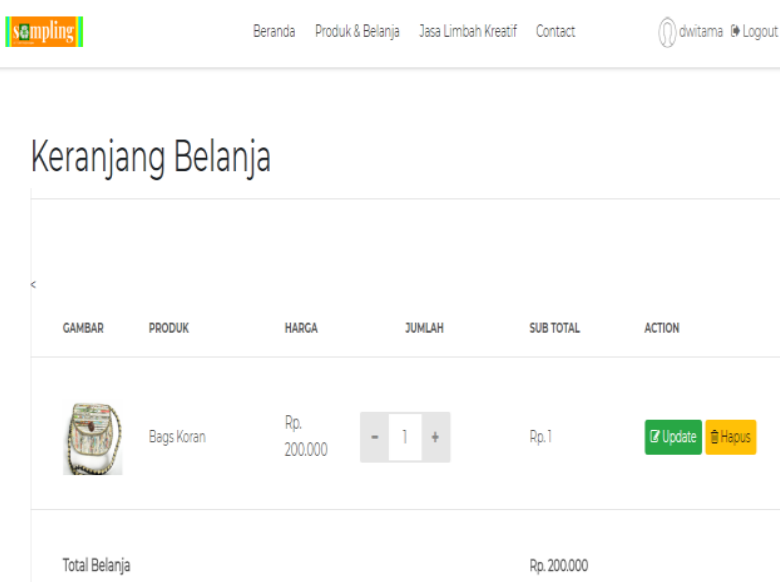

ÄBersihkan Belanja TL Lanjutkan Pembayarar

Gambar 3.3.6 Tampilan Keranjang belanja

7) Halaman Jasa

Halaman Jasa, untuk pengunung dan pelanggan.

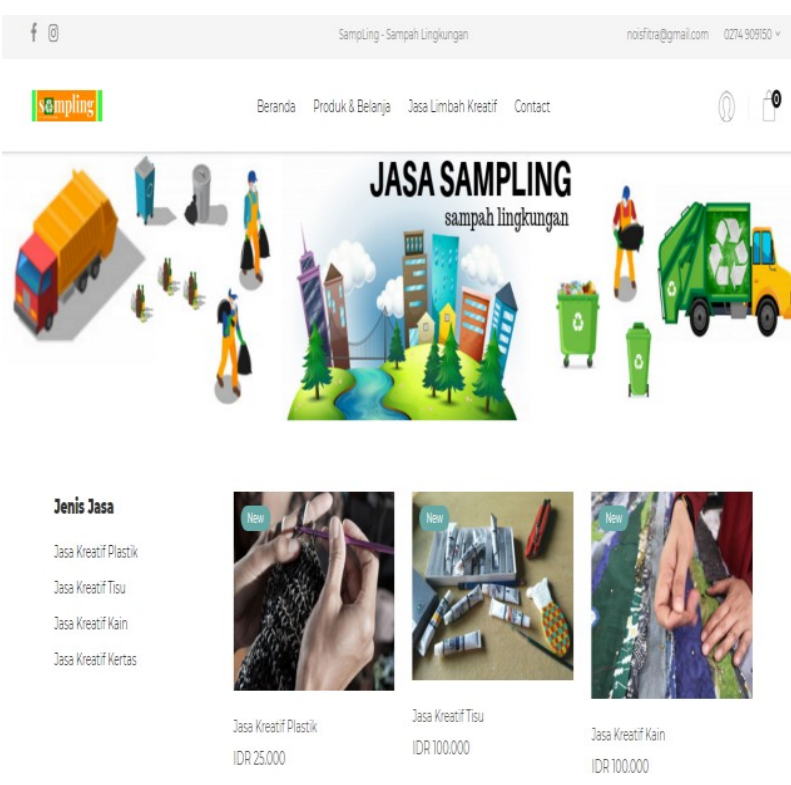

Gambar 3.3.7 Halaman Jasa
8) Halaman Formulir Setor Sampah

Halaman pengisian formulir, untuk melakukan pemesanan jasa.

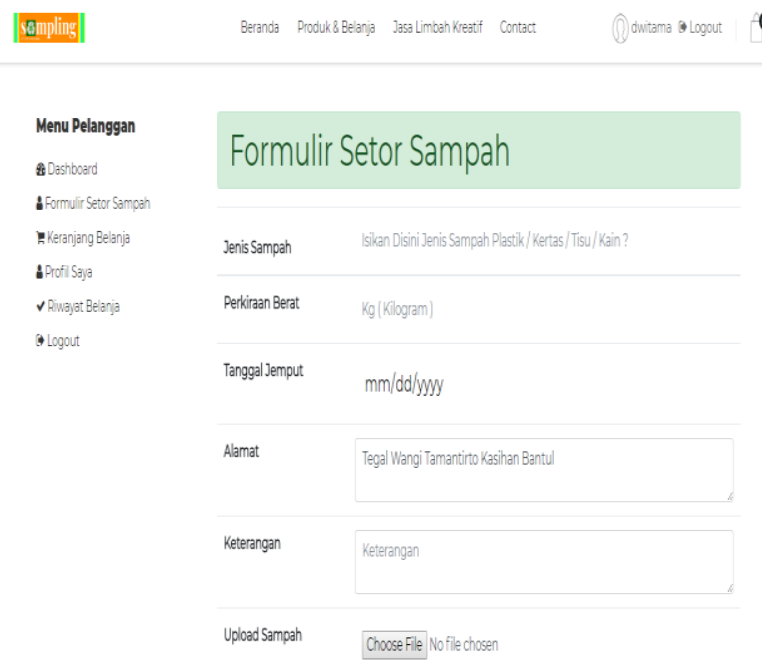

Gambar 3.3.8 Formulir setoran sampah

\section{Conclusions}

Berdasarkan hasil penelitian menggunakan metode pengembangan perangkat lunak RAD (Rapid Aplication Development) telah berhasil membangun sebuah aplikasi yang bernama aplikasi Sampling (sampah lingkungan) berbasis web. Aplikasi ini harapannya dapat dikembangkan dan diimplementasikan untuk pengolahan sampah lingkungan. Berdasarkan pengujian menggunakan blackbox testing menunjukkan hasil yang sesuia harapan. Dengan membuat website layanan Sampling (Sampah Lingkungan) dapat memudahkan pelanggan jika akan melakukan pembelian ataupun menggunakan layanan jasa pembuatan produk. Metode RAD (Rapid Aplication Development) terbukti mampu membantu pembangunan aplikasi sampilng selesai lebih cepat dan sesuai kebutuhan. 


\section{Acknowledgments}

Terima kasih kepada Universitas Bina Sarana Informatika yang sudah membantu serta mensupport jalannya penelitian. Serta terima kasih kepada pihak-pihak yang sudah membantu jalannya penelitian yang tidak bisa disebut satu persatu.

\section{References}

Andriani, A., \& Qurniati, E. (2018). Sistem Informasi Penjualan Pada Toko Online Dengan Metode Rapid Application Development (RAD). Journal Speed Sentra Penelitian Engineering Dan Edukasi, 10(3), 49-54. http://speed.web.id/ejournal/index.php/ speed/article/view/392/385

Buani, D. C. P., \& Suryani, I. (2020). Sistem Informasi Jasa Travel (SIJAVEL) Menggunakan Metode Waterfall. EVOLUSI: Jurnal Sains Dan Manajemen, 8(2), 50-55. https://doi.org/10.31294/evolusi.v8i2.8 759

Fauzi, A., \& Harli, E. (2017). Peningkatan Kualitas Pelayanan Melalui CRM dengan Metode RAD. Jurnal RESTI (Rekayasa Sistem Dan Teknologi Informasi), $\quad$ 1(1), 76. https://doi.org/10.29207/resti.v1i1.16 Huda, K. (2019). Pengembangan Sistem Informasi Pelaporan Sampah. 4(Sens
4), 349-358.

Kai, H. N., Sompie, S. R. U. A., Sambul, A. M., Elektro, T., Sam, U., Manado, R., \& Manado, J. K. B. (2018). Aplikasi Layanan Pengangkutan Sampah Berbasis Android. Jurnal Teknik Informatika, 13(4), 1-12. https://doi.org/10.35793/jti.13.4.2018.2 8088

Kusniawan, A. (2016). Perancangan Website Jasa Desain Interior Sebagai Media Pemasaran Studi Kasus: CV. Focalpoint Interior. Jurnal Evolusi, $4(2), 1-10$.

Marali, M. D., Pradana, F., \& Priyambadha, B. (2018). Pengembangan Sistem Aplikasi Transaksi Bank Sampah Online Berbasis Web ( Studi Kasus : Bank Sampah Malang ). 2(11), 56445650 .

Nurhadi, A. (2018). Penerapan Metode Waterfall Dalam Sistem Informasi Penyedia Asisten Rumah Tangga Secara Online. Jurnal Khatulistiwa Informatika, $\quad 6(2), \quad 97-106$. https://doi.org/10.31294/khatulistiwa.v $6 \mathrm{i} 2.150$

Purwat, N., \& Anggreani, N. (2020). Perancangan Sistem Informasi Penerimaan Jasa Servis pada CV. Java Multimedia Yogyakarta. 6(1), 33-43.

Rokhim, A., \& Romadhoni, K. (2020). Implementasi Metode Extreme 
Programming ( XP ) Pada Aplikasi

Bank Sampah Bina Usaha. Jurnal

Insand Comtech, 5(1), 1-7.

Setiadi, A. (2015). Studi Pengelolaan

Sampah Berbasis Komunitas pada

Kawasan Permukiman Perkotaan di

Yogyakarta. 3(April), 27-38.

Wahyuningrum, T., \& Januarita, D. (2014).

Perancangan Web e-Commerce

dengan Metode Rapid Application

Development ( RAD) untuk Produk

Unggulan Desa. 2014(November), 8188.

Wardhana, W. S., Tolle, H., \& Kharisma, A.

P. (2019). Pengembangan Aplikasi
Mobile Transaksi Bank Sampah Online

Berbasis Android ( Studi Kasus : Bank Sampah Malang ). Jurnal Pengembangan Teknologi Informasi Dan Ilmu Komputer, 3(7), 6548-6555. Yudhistirani, S. A., Syaufina, L., \& Mulatsih, S. (2016). Desain Sistem Pengelolaan Sampah Melalui Pemilahan Sampah Organik Dan Anorganik Berdasarkan Persepsi Ibu Ibu Rumah Tangga. Jurnal Konversi, 4(2),

https://doi.org/10.24853/konversi.4.2.2 $9-42$ 